\title{
Morpho-anatomy and physiology of red galangal (Alpinia purpurata) and white galangal (Alpinia galanga) under some salinity stress levels
}

\author{
TIA SETIAWATI ${ }^{1}$, ANIS SUSILAWATI ${ }^{1}$, ASEP ZAINAL MUTAQIN ${ }^{1}$, MOHAMAD NURZAMAN ${ }^{1}$, ANNISA $^{1}$, \\ RUHYAT PARTASASMITA ${ }^{1, \bullet}$, KARYONO ${ }^{1}$ \\ ${ }^{4}$ Department of Biology, Faculty of Mathematics and Natural Sciences, Universitas Padjadjaran. Jl. Raya Bandung-Sumedang Km. 21 Jatinangor, \\ Sumedang 45363, West Java, Indonesia. Tel./fax.: +62-22-7796412, `email: rp2010rikkyo@gmail.com; ruhyat.partasasmita@unpad.ac.id
}

Manuscript received: 14 December 2017. Revision accepted: 16 April 2018.

\begin{abstract}
Setiawati T, Susilawati A, Mutaqin AZ, Nurzaman M, Annisa, Partasasmita R, Karyono. 2018. Morpho-anatomy and physiology of red galangal (Alpinia purpurata) and white galangal (Alpinia galanga) under some salinity stress levels. Biodiversitas 19: 809-815. Soil salinity is one of the most urgent issues in agriculture as it can reduce plant growth and productivity. Efforts on development of galangal plant on saline soils are still encountering some obstacles such as lack of information on the galangal types that are tolerant to saline condition. The purpose of this study was to determine morpho-anatomical and physiological responses of red galangal (Alpinia purpurata (Vieill.) K. Schum.) and white galangal (Alpinia galanga (L.) Willd.) to salinity stress treatments. This research used a Randomized Block Design (RBD) assigned in a factorial treatment design of two factors, i.e., (i) species of galangal consisting of two levels i.e., red galangal and white galangal, (ii) $\mathrm{NaCl}$ concentration consisting of five levels, i.e., $0 \%$, $3 \%$, $6 \%$, $9 \%$ and $12 \%$. Each treatment was three replicates. Observation was done on the growth parameters when the plants showed wilting symptoms. The observed data were subjected to Analysis of Variance (ANOVA), followed by a post hoc Duncan Multiple Range Test (DMRT) at $\alpha 5 \%$ when the treatment effect was significant. The results showed that salinity stress treatment significantly reduced the plant height increase, leaf area, dry weight, stomata density, chlorophyll content and increased thickness of root epidermis, and proline content in both species of galangal. Red galangal was more tolerant than white galangal.
\end{abstract}

Keywords: Galangal, morpho-anatomy, physiology, salinity stress

\section{INTRODUCTION}

Galangal is one of the herbal ingredients that have been widely used by the community as traditional medicine. The utilization of galangal as a herbal medicine material is increasingly widespread along with the discovery of its various biological activities such as immunomodulator (Weidner et al. 2007), high blood pressure lowering capacity, and fertility enhancer by increasing the number and motility of sperm (Chudiwal et al. 2010). Active substances of acetoxychavicol acetate (ACA) contained in galangal can inhibit the development of HIV (Ying and Baoan 2006), and can serve as antitumor, antioxidant and antimicrobial (Vankar et al. 2006). There are two kinds of galangal, i.e., the white tuber galangal called white galangal (Alpinia galanga (L.) Willd) commonly used as food seasonings and the red tuber galangal called red galangal (Alpinia purpurata (Vieill.) K. Schum) used as medicine (Lestari 2005).

The development of traditional medicine industry and other industries using galangal as raw material causes galangal demand tends to increase in the recent years, which necessitates cultivation efforts that can ensure the continuous availability of galangal. One of the attempts to increase the galangal production is by expanding the planting area. Land that has good prospects for agricultural development is marginal land, but technological innovation is required to improve the productivity of the marginal land
(Yuwono 2009), such as saline soil (Akbar 2010). Saline soil is a soil containing high dissolved $\mathrm{NaCl}$ salt with a $\mathrm{pH}$ of $<8.5$ and electrical conductivity of $>4 \mathrm{mmhos} / \mathrm{cm}$ so that it can interfere the plant growth (Follet et al. 1981), and consequently, it can decrease crop productivity.

Salinity affects many physiological and morphology processes of a plant by affecting the osmotic potential of soil solution and ion absorption and mineral accumulation (Ramezani et al. 2011). Salinity induces a variety of disorders at the cellular and whole plant levels. Salinity stress is produced from a number of adverse processes including the toxicity of $\mathrm{Na}^{+}$and $\mathrm{Cl}^{-}$ion, the impairment of mineral nutrition, water status modification of plant tissue and secondary stresses such as an oxidative stress associated with the production of toxic reactive oxygen intermediates (Bajji et al. 1998). As reported by Munns and Tester (2008) that salt stress on plants leads to a reduction in growth as a consequence of some physiological responses, including alterations of ion balance, water status, mineral nutrition, stomatal behavior, photosynthesis efficiency, and allocation and utilization of carbon. Soil salinity can affect plant growth both physically (osmotic effects) and chemically (nutrients and/or toxicity effects). Plants will be more difficult to absorb water as the soil salinity content increases. Sensitive plants appeared suffering from drought even though the salt content is quite low. There is usually a progressive decrease in growth and yield as salinity increases (Ogle and John 2010). 
In general, the response of plants to salinity can be seen from the morphology, anatomy, and physiology characteristics that are closely related to the production of plants in water-shortage environments ( $\mathrm{Li}$ et al. 2006). Salt tolerant plants are able to minimize adverse effects by producing a series of anatomical, morphological and physiological adaptations (Hameed and Ashraf 2008). Under high salt content, especially chloride and sodium, plants modify their anatomical properties. This is caused by osmotic effects and ionic imbalances that affect plants metabolism. Anatomically, it affects cell division and expansion process and reduces the size of meristem, cortex and vascular cylinder (Singh and Chaturvedi 2014) to minimize the detrimental effects of salt stress (Younis et al. 2014).

One of the efforts in the management of saline land is by using plant species that have good adaptation and tolerance to high salt content. Research on salinity has been widely carried out but information on the effect of salinity on Zingiberaceae plant growth, especially galangal, has not been reported. Therefore, it is necessary to study the effect of salinity on the growth of red galangal plants $(A$. purpurata) and white galangal (A. galanga) based on morphological, anatomical and physiological characteristics as indicators for identification of saline tolerant types of galangal.

\section{MATERIALS AND METHODS}

\section{Materials}

The seedlings of red galangal and white galangal were obtained from Horticultural Seed Center, Department of Food Crops and Horticulture, Hegarmanah Village, Jatinangor Sub-district, West Java Province. Planting medium used consisted of a mixture of sand and manure (2: 1). $\mathrm{NaCl}$ solution was used for salinity stress treatments.

\section{Methods}

This research used a Randomized Block Design (RBD) and a factorial treatment design. The treatments design included two factors: (i) species of galangal consisting of two levels, i.e., red galangal and white galangal, (ii) $\mathrm{NaCl}$ concentration consisting of five levels, i.e., $0 \%$, $3 \%$, $6 \%$, $9 \%$ and $12 \%$. Each treatment consisted of three replicates. The research was carried out in the Laboratory of Biosystem and Greenhouse, Department of Biology, Padjadjaran University, Sumedang, Indonesia during March-June 2017.

\section{Procedures}

Three months old and homogenous seedlings of red galangal and white galangal were used in the study. Seedlings were planted in mixtures of sand and manure (2: 1) media contained in plastic pots and acclimatized for two weeks in a greenhouse before the salinity stress treatments were applied (Syakir et al. 2008). The salinity treatment was applied by watering the plants using $\mathrm{NaCl}$ solution according to a predetermined concentration $(0,3,6,9$ and $12 \%$ ) every two days with the volume of field capacity
(Ramezani et al. 2011). Field capacity (FC) was determined based on a gravimetric method using the following formula: $\mathrm{FC}=\mathrm{WW}-\mathrm{DW}) / \mathrm{DW} \times 100 \%$, where $\mathrm{WW}=$ wet weight and DW = dry weight of soil. Pots with dry soil were weighed to obtain dry weight and were watered to a saturated level, allowed to drain for 24 hours and weighed again.

\section{Parameter measurement}

Observations were made on the plant growth parameters when plants showed the symptom of wilting. The parameters observed were morphological, anatomical and physiological characteristics including plant height increase, leaf area, plant dry weight, stomata density, thickness of root epidermis, thickness of root cortex, root trachea number, chlorophyll and proline contents. Plant height increase is the difference between the plant height at the start of the treatment applied and that at the end of observation. The initial plant height was measured at the time of drought stress treatment was applied while the final plant height was measured when the plant showed wilting symptoms ( 24 days after the treatment was applied). Leaf area was measured using a leaf area meter CI-202 portable laser. Dry weight was measured by drying the plant materials in an oven at a temperature of $70^{\circ} \mathrm{C}$ to obtain a constant weight. Chlorophyll content was measured with chlorophyll meter Opti-Science CCM-20. The stomata density was observed using transparent nail polish applied to the leaf surface. The nail polish was spread to a small portion of the lower surface of the leaf and then peeled away slowly. Replica of stomata was examined under a light microscope with a magnification of $400 \mathrm{x}$ (Shrestha and Kang 2016). Root anatomical observations included the thickness of epidermis and the thickness of cortex that were performed by making fresh preparations of the transverse incision of the roots and observed under a light microscope. Proline content was measured following the method by Bates et al. (1973). Leaf samples of $0.5 \mathrm{~g}$ were extracted with a $3 \%$ sulfo-salicylate solution. The filtrate was reacted with ninhydrin reagent, and then extracted with toluene. The red toluene containing proline was separated and the proline content was measured by using a spectrophotometer, absorbance was read at $520 \mathrm{~nm}$ wavelength. Proline content was determined using calibration curve and expressed as $\mathrm{mg} \mathrm{g}^{-1}$ fresh weight.

\section{Data analysis}

Data analysis was done statistically using Analysis of Variance (ANOVA) and Duncan Multiple Range Test at significance level $95 \%$. The relative stress tolerance was determined based on the salt stress sensitivity index (SI) calculated following the Fischer and Maurer (1978) equation, i.e., $\mathrm{SI}=(1-\mathrm{Yp} / \mathrm{Y}) /(1-\mathrm{Xp} / \mathrm{X})$, where: $\mathrm{SI}=$ index of salt stress sensitivity, $\mathrm{Yp}=$ the mean of a genotype in stress environment, $\mathrm{Y}=$ the mean of a genotype in non stress environment, $\mathrm{Xp}=$ the mean of all genotypes in stress environment, $\mathrm{X}=$ the mean of all genotypes in non stress environment. The genotype is categorized tolerant to stress if it has a value of SI $<0.5$, moderately tolerant if 0.5 $\leq \mathrm{SI} \leq 1$, and susceptible if $\mathrm{SI}>1$. 


\section{RESULTS AND DISCUSSION}

\section{Plant height increase}

The increase in plant height was measured by calculating the difference between the plant heights at the beginning of the treatment was applied and that at the end of the observation, i.e., when the plants showed wilting symptoms. In this study, plants exhibited the signs of wilting at 24 days after treatment was applied. Results showed that concentration of $\mathrm{NaCl}$ significantly affected the average of plant height increase $(\mathrm{P}<0.05)$ but the difference of galangal species and interaction of both factors have no significant effect $(\mathrm{P}>0.05)$ on the observed parameter. The mean plant height increase under various treatments of $\mathrm{NaCl}$ concentration can be seen in Table 1 .

Table 1 shows that the average plant height decreased significantly with the increase of $\mathrm{NaCl}$ concentration of up to $12 \%$. At a $\mathrm{NaCl}$ concentration of $3 \%$, the average plant height was $1.17 \mathrm{~cm}$, which did not differ significantly from that of the control treatment $(0 \% \mathrm{NaCl})$ but differed significantly from other $\mathrm{NaCl}$ treatments. These results indicated that the galangal plant is able to adapt to $\mathrm{NaCl}$ concentration of 3\%o. Yadav et al. (2001) stated that plant growth including the plant height increase would be inversely proportional to salinity levels. The present study result was in line with the study results of Kamrani et al. (2013) in Brassica napus L. showing that growth of plant height decreased as the salinity concentration increased to $350 \mathrm{mM}$. Increasing the salinity concentration caused a significant decrease in the height increase of galangal (Table 1). This condition was probably caused by the reduction in turgor pressure within the cells that restricted cell expansion (Jampeetong and Brix 2009); consequently, the increase of height was declined. Munns (1993) also reported that under salt stress, accumulation of salt did occur in older leaves that expedite their death. As a consequence of these leave loss, the supply of carbohydrate and growth hormone to the meristematic areas will decrease. This can lead to constrain the plant height growth that occurs in the stems apical meristem.

\section{Leaf area}

Research results revealed that $\mathrm{NaCl}$ concentration significantly affected leaf area $(\mathrm{P}<0.05)$ but the interaction of the two factors had no significant effect $(\mathrm{P}>0.05)$ on the trait. Average leaf area of the two galangal species under various levels of $\mathrm{NaCl}$ concentration is presented in Table 2 .

The average leaf area was significantly different among the two galangal species and also the $\mathrm{NaCl}$ concentration treatments (Table 2). The average leaf area of white galangal was higher than red galangal. This result showed that different species of galangal plants had different phenotypes (leaf areas), presumably due to differences in the genetic background of the two galangal species.

Table 2 also shows that the increase of $\mathrm{NaCl}$ concentration caused a significant decrease in the average leaf area of galangal. The average leaf area at the concentration of $6 \% \mathrm{NaCl}\left(51.62 \mathrm{~cm}^{2}\right)$ was not significantly different from that of the control treatment $(\mathrm{NaCl} 0 \%)$. This result indicated that for the leaf area variable, the galangal species were tolerant to $\mathrm{NaCl}$ concentrations of up to $6 \%$. Each plant has the ability to adapt and tolerate stress to a certain concentration. Leaf growth restriction under salinity stress is mainly due to the osmotic effects of salt around the roots, leading to decrease water supply to leaf cells (Cassaniti et al. 2012). Younis et al. (2014) reported that under high saline stress there was a reduction of water uptake by plants which created osmotic conditions and ionic toxicity resulting in smaller cell size and cell injury. This may cause a decrease in leaf area. Curtis and Lauchi (1987) found that the decrease in leaf area was caused by the decrease in cell size rather than the cell number. The decrease in cell size could be due to the decrease in osmotic potential of leaf cells. Similar to our results, Brugnoli and Lauteri (1991) also recorded that leaf area development was strongly reduced by salinity in cotton and bean.

\section{Dry weight}

The present study showed that galangal species by $\mathrm{NaCl}$ concentration interaction effect was significant $(\mathrm{P}<0.05)$ on the plant's dry weight. The average dry weight due to interaction effects of both factors is shown in Table 3.

$\mathrm{NaCl}$ treatment caused a decrease in average dry weight of the galangal plant (Table 3 ). The highest average dry weight of the galangal plant $(6.22 \mathrm{~g})$ was observed in the white galangal treated with $6 \% \mathrm{NaCl}$, which was not significantly different from that of the same galangal species without $\mathrm{NaCl}(0 \% \mathrm{NaCl})$. The lowest average dry weight was found in red galangal at $12 \% \mathrm{NaCl}(4.57 \mathrm{~g})$. Similar to our result, Turan et al. (2009) also reported that the effect of salinity on corn growth showed a negative correlation. The $100 \mathrm{mM} \mathrm{NaCl}$ concentration significantly decreased the dry weight of the plant up to $45.46 \%$ as compared to the control $(0 \mathrm{mM})$. Ceccoli et al. (2011) also reported similar results in Chloris gayana plants, where there was a decrease in total dry weight at high $\mathrm{NaCl}$ concentration $(250 \mathrm{mM})$.

Dry weight is often measured to indicate the growth of plants and cells in response to saline environment (Bekheet 2015). The decrease of dry weight on salt-exposed plants was due to the destruction of salt-induced photosynthetic tissue, the reduction of water potential and high accumulation of $\mathrm{Na}+$ and Cl-(Ashraf et al. 2008). Also, according to Curtis and Lauchli (1986) increased salinity has an inverse relationship with stomatal conductance and net photosynthetic rate. This condition will cause reduction of the plant dry weight. According to Lopez et al. (2009), salinity stress will alter the metabolism to overcome the stress that causes growth to decrease. Also, this decrease is the effect of plant defense mechanisms to reduce greater salinity exposure.

\section{Stomatal density}

The results of ANOVA showed that difference of galangal species, $\mathrm{NaCl}$ concentration, and its interaction did not significantly affect the stomatal density $(\mathrm{P}>0.05)$. Stomatal density in both species of galangal at different concentrations of $\mathrm{NaCl}$ is shown in Figure 1. Figure 1 shows that stomatal density did decrease along with the 
increase of salinity in both species of galangal. The white galangal (A. galanga) had a higher average stomatal density than the red galangal at all $\mathrm{NaCl}$ concentrations. These results indicated that the white galangal plant was more tolerant to salinity than the red galangal. In the $\mathrm{NaCl}$ treatments, the lowest average stomatal density was found in $12 \% \mathrm{NaCl}$, i.e., 77.45 cells/wide field of view and 75.31 cells/wide field of view in red galangal and white galangal, respectively. Similar results were found on stomatal density in leaves of Kandelia candel (Qiu et al. 2007), Simmondsia chinensis (Ali et al. 2013), where the stomatal density did decline with the increase of salinity. Reginato et al. (2013) reported that $\mathrm{NaCl}$ treated $P$. strombulifera plants showed a significant decrease of $40 \%$ in stomatal density at high salinity $\left(\Psi_{0}=-2.6 \mathrm{MPa}\right)$. Barbieri et al. (2012), in a study employing two basil (Ocimum basilicum L.) cultivars (Napoletano and Genovese) with different ability to respond to salt stress showed that reduced stomatal density, high ascorbate level and polyphenol oxidase activity coordinately contributed to improve adaptation of basil and Water Use Efficiency (WUE) in saline environment. The constitutively reduced stomatal density was associated with a "delayed" accumulation of stress molecules (and growth inhibiting signals) such as ABA and proline, in the more tolerant basil cultivar (Genovese).

\section{The thickness of epidermis and cortex}

Anova results showed that concentration of $\mathrm{NaCl}$ significantly affected the average thicknesses of root epidermis and cortex $(\mathrm{P}<0.05)$, but galangal species and the interaction of galangal species by $\mathrm{NaCl}$ concentration caused no significant effect $(\mathrm{P}>0.05)$ on the observed variables. Mean epidermis and cortex thicknesses of galangal root at different $\mathrm{NaCl}$ concentration treatments are presented in Table 4.

Table 4 shows that the average thickness of root epidermis increased significantly with an increase in $\mathrm{NaCl}$ concentration. The galangal plants treated with $\mathrm{NaCl}$ concentration of $12 \%$ resulted in the highest average epidermis thickness $(19.67 \mu \mathrm{m})$. The average thickness of the root epidermis at the $\mathrm{NaCl}$ concentrations of $3 \%$ and $6 \%$ did not differ significantly from the control treatment. This indicated that the galangal plant was able to adapt well to salinity stress conditions of up to $6 \% \mathrm{NaCl}$. The increase in epidermal cells is an attempt to reduce the entry of excess salt and protect the underlying tissue (Turan et al. 2009). The thickness of the root epidermis will increase in species that are tolerant to high salinity condition because the thickness of the epidermis is a special character exhibited by tolerant species (Awasthi and Pathak 1999).

In contrast to root epidermis, the average thickness of root cortex decreased significantly along with the increase of $\mathrm{NaCl}$ concentration. The highest decrease in thickness of root cortex $(17.83 \mu \mathrm{m})$ was observed at $\mathrm{NaCl}$ concentration of $12 \%$ (Table 4 ). The decrease in cortex thickness is the root response of plants against salinity stress. Salinity can cause changes in the cell structure of plant roots such as increasing the thickness of the epidermis as a way to reduce the increased salt exposure and the decrease in cortex thickness as the effect of the reduced food supply so that the turgidity of cells in the cortex is decreased. Ceccoli et al. (2011) also reported that the root diameter of the Chloris gayana Kunth did decrease with increased salinity. This indicates that the thickness of the root cortex also decreases as salinity increases. Reduction of the cortex thickness due to salt stress was also found in other plants such as soybean (Dolatabadian et al. 2011) and Gazania harlequin (Younis et al. 2014).

\section{Chlorophyll content}

Each of the single factors of galangal species and $\mathrm{NaCl}$ concentration significantly affected chlorophyll content $(\mathrm{P}<0.05)$, but the interaction of these two factors had no significant effect $(P>0.05)$ on the observed variable. Chlorophyll content of galangal plant under different galangal species and $\mathrm{NaCl}$ concentration are presented in Table 2 .

Table 2 shows that the chlorophyll content of red galangal $(20.40 \mathrm{CCI})$ was significantly higher than that of white galangal $(16.90 \mathrm{CCI})$. The difference in chlorophyll content of the two galangal species might have been due to variations in individual genes controlling the trait. Gardner et al. (2003) stated that the growth and crop yield are influenced by internal factors such as the genetic trait, i.e., an inherited specific element owned by the plant itself. The average chlorophyll content was observed decrease with the increase of $\mathrm{NaCl}$ concentration. The lowest average chlorophyll content $(8.93 \mathrm{CCI})$ was observed at the $\mathrm{NaCl}$ concentration treatment of $12 \%$. The $\mathrm{NaCl}$ treatment of $6 \%$ produced an average chlorophyll content that was similar to that of either control $(0 \% \mathrm{NaCl})$ or $3 \% \mathrm{NaCl}$ treatment but was significantly different from that of $9 \%$ and $12 \% \mathrm{NaCl}$ treatments. This showed that the galangal plant was able to tolerate a salinity condition of up to $6 \%$ o $\mathrm{NaCl}$ for chlorophyll content trait.

Table 2 indicates a decrease in chlorophyll content due to $\mathrm{NaCl}$ treatment. This decrease of chlorophyll levels may be due to increased degradation and synthesis inhibition of chlorophyll pigment (Stepien and Klobus 2006). The previous study by Zhao et al. (2007) revealed that the effect of salinity on chlorophyll content could lead to inhibition of chlorophyll synthesis and thus the chlorophyll content will decrease. The chlorophyll biosynthesis barriers may be due to the accumulation of the salts (Ali et al. 2004). Na accumulation has an adverse effect on $\mathrm{Mg}$ and $\mathrm{Ca}$ contents in leaves because $\mathrm{Na}$ will inhibit $\mathrm{Mg}$ and $\mathrm{Ca}$ absorptions. The decrease of $\mathrm{Ca}$ content in leaf increases the permeability of the membrane to salt, while $\mathrm{Mg}$ deficiency will cause inhibition of chlorophyll biosynthesis (Delfine et al. 1998), particularly in the pre-protochlorophyll stage in the chlorophyll biosynthesis pathway (Chen et al. 1998). Disturbance of chlorophyll formation also occurs in plants that have decreased total nitrogen uptake as a critical element in chlorophyll formation along with increased salinity (Pessarakli 1994). Similar results were also reported by Mahboobeh and Akbar (2013), where the total chlorophyll content of Nicotiana plumbaginifolia leaves decreased with the increase of $\mathrm{NaCl}$ concentration. The decrease in chlorophyll content with increased soil salinity was also reported by Jaleel et al. (2008). 
Table 1. Average plant height increase of galangal at different $\mathrm{NaCl}$ concentration at 24 days after treatment

\begin{tabular}{lc}
\hline NaCl concentration & Plant height increase (cm) \\
\hline $0 \% 0$ & $1.67 \mathrm{c}$ \\
$3 \% 0$ & $1.17 \mathrm{c}$ \\
$6 \%$ & $0.83 \mathrm{ab}$ \\
$9 \% 0$ & $0.50 \mathrm{ab}$ \\
$12 \%$ & $0.17 \mathrm{a}$ \\
\hline
\end{tabular}

Note: Means followed by the same letter are not significantly different at 5\% DMRT

Table 2. Average leaf area and chlorophyll content of galangal plants under single factor treatments; the galangal species and levels of $\mathrm{NaCl}$ concentration

\begin{tabular}{lcc}
\hline Treatments & $\begin{array}{c}\text { Average leaf } \\
\text { area }\left(\mathbf{c m}^{2}\right)\end{array}$ & $\begin{array}{c}\text { Chlorophyll } \\
\text { content (CCI) }\end{array}$ \\
\hline $\begin{array}{l}\text { Galangal species } \\
\text { A. purpurata (red galangal) }\end{array}$ & $40.60 \mathrm{a}$ & \\
A. galanga (white galangal) & $56.90 \mathrm{~b}$ & $16.90 \mathrm{~b}$ \\
& & \\
NaCl concentrations & & \\
$0 \% \mathrm{o}$ & $54.23 \mathrm{~b}$ & $24.15 \mathrm{c}$ \\
$3 \% \mathrm{0}$ & $52.98 \mathrm{~b}$ & $22.55 \mathrm{c}$ \\
$9 \%$ & $51.62 \mathrm{~b}$ & $21.05 \mathrm{c}$ \\
$9 \%$ & $44.32 \mathrm{a}$ & $16.57 \mathrm{~b}$ \\
$12 \% 0$ & $40.58 \mathrm{a}$ & $8.93 \mathrm{a}$ \\
\hline
\end{tabular}

Note: Means followed by the same letter in the same treatment group are not significantly different at the $5 \%$ DMRT

Table 3. Average dry weight (g) of galangal under galangal species by $\mathrm{NaCl}$ concentration interaction effect

\begin{tabular}{lccccc}
\hline \multirow{2}{*}{ Galangal species } & \multicolumn{5}{c}{ NaCl concentration } \\
& $\mathbf{0 \%}$ & $\mathbf{3 \%}$ & $\mathbf{6 \%}$ & $\mathbf{9 \% o}$ & $\mathbf{1 2 \%}$ \\
\hline Red galangal & $4.83 \mathrm{bc}$ & $4.76 \mathrm{ab}$ & $4.65 \mathrm{a}$ & $5.76 \mathrm{~d}$ & $4.57 \mathrm{a}$ \\
White galangal & $6.22 \mathrm{ef}$ & $5.91 \mathrm{de}$ & $6.22 \mathrm{ef}$ & $5.38 \mathrm{c}$ & $5.04 \mathrm{~b}$ \\
\hline
\end{tabular}

Note: Means followed by the same letter are not significantly different at the $5 \%$ level by DMRT

Table 4. Average epidermis and cortex thicknesses of galangal root at different $\mathrm{NaCl}$ concentration

\begin{tabular}{lcc}
\hline $\begin{array}{l}\text { NaCl } \\
\text { concentration }\end{array}$ & $\begin{array}{c}\text { Average epidermis } \\
\text { thickness }(\boldsymbol{\mu m})\end{array}$ & $\begin{array}{c}\text { Average cortex } \\
\text { thickness }(\boldsymbol{\mu m})\end{array}$ \\
\hline $0 \% 0$ & $17.17 \mathrm{a}$ & $29.50 \mathrm{~d}$ \\
$3 \% 0$ & $17.33 \mathrm{a}$ & $22.83 \mathrm{c}$ \\
$6 \%$ & $17.83 \mathrm{a}$ & $20.67 \mathrm{bc}$ \\
$9 \% 0$ & $18.83 \mathrm{~b}$ & $18.67 \mathrm{ab}$ \\
$12 \% 0$ & $19.67 \mathrm{~b}$ & $17.83 \mathrm{a}$ \\
\hline
\end{tabular}

Note: Means followed by the same letter are not significantly different at the $5 \%$ level by DMRT

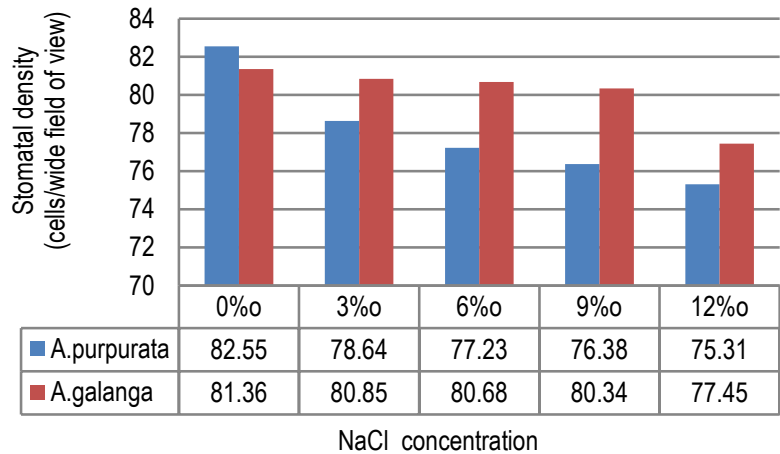

Figure 1. The average stomatal density of galangal at different concentration of $\mathrm{NaCl}$

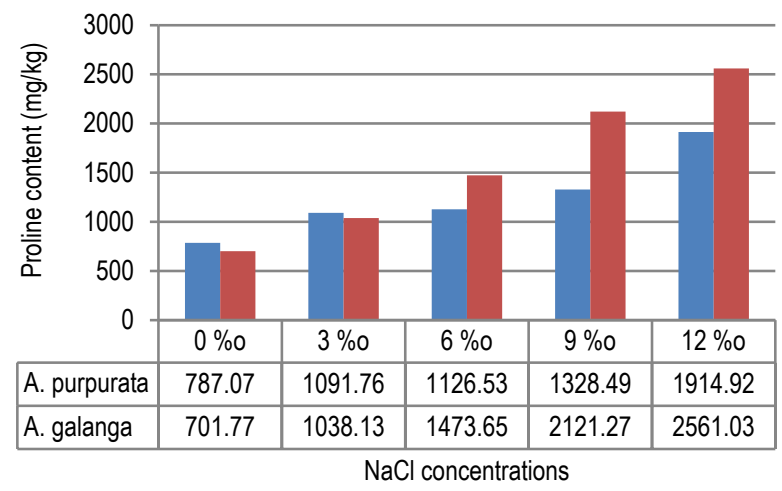

Figure 2. Average proline content of galangal on the different $\mathrm{NaCl}$ concentrations

\section{Proline content}

Proline content of leaves of red galangal and white galangal at different concentrations of $\mathrm{NaCl}$ can be seen in Figure 2. Figure 2 shows that the average proline content did increase along with the increasing salinity level. The highest proline content of red galangal and white galangal were $1914.92 \mathrm{mg} \mathrm{kg}^{-1}$ and $2561.03 \mathrm{mg} \mathrm{kg}^{-1}$, respectively, or increased by $143.61 \%$ and $264.93 \%$, respectively. This result was similar to that reported by Farhoudi et al. $(2015)$ that the treatment of $\mathrm{NaCl}$ watering with levels of $0.6,4$ and $8 \mathrm{dS} \mathrm{m}^{-1}$ in some rapeseed cultivars increased proline content as $\mathrm{NaCl}$ levels increased.

Proline is the dominant organic molecule acting as an osmotic mediator during saline conditions, a balancer of cellular structures, energy reserves, and signal related to plant stress (Benhassaini et al. 2012), osmoprotectants under stress conditions, and serve to maintain membrane structure and acting as free radical scavengers which prevents lipid peroxidation and $\mathrm{K}+$ channels regulator in stomata (Parida and Das 2005). High proline content is known to protect various enzyme systems against dehydration process (Fagbola et al. 2001). Under saline stress, the stress-resistant genotypes accumulated proline at a higher level than the stress-sensitive one (Soheilikhah et al. 2013). 
Table 5. The tolerance level of eight observation parameters based on sensitivity index (SI) salinity stress

\begin{tabular}{|c|c|c|c|c|}
\hline \multirow[t]{2}{*}{ Parameter } & \multicolumn{2}{|c|}{ A. pupurata (red galangal) } & \multicolumn{2}{|c|}{ A. galanga (white galangal) } \\
\hline & Sensitivity Index & Category & Sensitivity Index & Category \\
\hline Plant height increase & 0.833 & Moderately tolerant & 1.167 & Sensitive \\
\hline Leaf area & 0.711 & Moderately tolerant & 1.195 & Sensitive \\
\hline Stomatal density & 0.429 & Tolerant & 1.563 & Sensitive \\
\hline Epidermis thickness & 1.717 & Sensitive & 0.507 & Moderately tolerant \\
\hline Cortex thickness & 1.001 & Sensitive & 0.999 & Moderately tolerant \\
\hline Proline content & 0.947 & Moderately tolerant & 1.039 & Sensitive \\
\hline
\end{tabular}

Table 6. Scores of sensitivity level of galangal plants to salinity stress based on sensitivity index (SI)

\begin{tabular}{|c|c|c|c|c|c|c|c|c|c|c|}
\hline \multirow[t]{2}{*}{ Species } & \multicolumn{3}{|c|}{ Tolerant } & \multicolumn{3}{|c|}{$\begin{array}{c}\text { Sensitivity level } \\
\text { Moderately tolerant }\end{array}$} & \multicolumn{3}{|c|}{ Sensitive } & \multirow[t]{2}{*}{ Total } \\
\hline & Parameter & Value & Score & Parameter & Value & Score & Parameter & Value & Score & \\
\hline Red galangal & 2 & 2 & 4 & 4 & 1 & 4 & 2 & 0 & $\mathbf{0}$ & 8 \\
\hline White galangal & 0 & 2 & $\mathbf{0}$ & 2 & 1 & 2 & 6 & 0 & $\mathbf{0}$ & 2 \\
\hline
\end{tabular}

\section{Salinity stress susceptibility level of galangal plants}

Salinity stress susceptibility level of the tested galangal species was determined by calculating sensitivity index (SI) based on the eight observed parameters (Tables 5 and 6). Table 5 shows that the red galangal was tolerant to salt stress on the parameters of dry weight and stomatal density and was sensitive to the parameters of epidermis and cortex thickness; meanwhile, the white galangal was sensitive to six parameters of eight observed parameters except for the epidermis and cortex thickness that showed a moderate tolerant phenotype. The most tolerant galangal species was determined by calculating the total score of each tolerance level as follows: tolerant $=2$, moderately tolerant $=1$ and sensitive $=0$ (Syafi 2008) as presented in Table 6 .

Based on the sensitivity level, the red galangal $(A$. purpurata) showed a higher total score (8) than white galangal (A. galanga) with the total score of 2 (Table 6). This indicated that the red galangal (A. purpurata) was more tolerant to $\mathrm{NaCl}$ salt stress than the white galangal $(A$. galanga). Differences of plant species can result in different adaptability and tolerance capabilities to environmental stresses such as salinity. Aini et al. (2012) suggested that plant responses to salinity stress differ in species or genotype.

The observation result is expected to be used as a reference for subsequent research that may be useful in saline land management efforts for the development of cultivation of the more salt stress tolerant red galangal as compared to the white galangal.

\section{ACKNOWLEDGMENTS}

The authors are thankful to Rector of Padjadjaran University for financial support under Academic Leadership Grant (ALG) of Prof. Karyono.

\section{REFERENCES}

Adebooye OC, Hunsche M, Noga G, Lankes C. 2012. Morphology and density of trichomes and stomata of Trichosanthes cucumerina (Cucurbitaceae) as affected by leaf age and salinity. Turk J Bot 36: 328-335.

Aini N, Mapfumo E, Rengel Z, Tang C. 2012. Ecophysiological responses of Melaleuca species to dual stresses of water logging and salinity. Intl J Plant Physiol Biochem 4 (4): 52-58.

Akbar R. 2010. Screening of several varieties of soybean (Glycine max L. Merril.) to some concentrations of $\mathrm{NaCl}$ salt in in-vitro culture. Universitas Sumatera Utara, Medan. [Indonesian].

Ali Y, Aslam Z, Ashraf MY, Tahir GR. 2004. Effect of salinity on chlorophyll concentration, leaf area, yield and yield components of rice genotypes grown under saline environment. Intl J Environ Sci Technol 1 (3): 221-225.

Awasthi OP, Pathak RK. 1999. Effect of salinity levels on survival and anatomy of four scion cultivars budded on Indian jujube. Horticulture J 12: 53-59.

Bajji M, Kinet JM, Lutts S. 1998. Salt stress effects on roots and leaves of Atriplex halimus L. and their corresponding callus cultures. Plant Sci 137: 131-142.

Barbieri G, Vallone S, Orsini F, Paradiso R, De Pa-scale S, NegreZakharov F, Maggio A. 2012. Stomatal density and metabolic determinants mediate salt stress adaptation and water use efficiency in basil (Ocimum basilicum L.). J Plant Physiol 169 (17): 1737-1746.

Bates LS, Walden RP, Teare ID. 1973. Rapid determination of free proline for water studies. Plant Soil 39: 205-208.

Benhassaini H, Fetati A, Hocine AK, Belkhodja M. 2012. Effect of salt stress on growth and accumulation of proline and soluble sugars on plantlets of Pistacia atlantica Desf. subsp. atlantica used as rootstocks. Biotechnol Agron Soc Environ 16 (2): 159-165.

Brugnoli E, Lauteri M. 1991. Effects of salinity on stomatal conductance, photosynthetic capacity, and carbon isotope discrimination of salttolerant (Gossypium hirsutum L.) and salt-sensitive (Phaseolus vulgaris L.) C3 non-halophytes. Plant Physiol 95: 628-635.

Cassaniti C, Romano D, Flowers TJ. 2012. The response of ornamental plants to saline irrigation water. In: Garcia-Garizabal I (ed.). Irrigation -Water Management, Pollution, and Alternative Strategies. InTech, Rijeka, Croatia.

Ceccoli G, Ramos JC, Ortega L, Acosta JM, Perreta MG. 2011. Pollution and alternative strategies: salinity induced anatomical and morphological changes in Chloris gayana Kunth. roots. Biocell 35 (1): 9-17. 
Chen DM, Keiper FJ, Filippis, De LF. 1998. Physiological changes accompanying the induction of salt tolerance in Eucalyptus microcorys shoots in tissue culture. J Plant Physiol 152: 555-563.

Chudiwal AK, Jain DP, Somani RS. 2010. Alpinia galanga Willd. An overview of phyto-pharmacological properties. Indian J Nat Prod Resour 1 (2): 143-149.

Curtis PS, Lauchli A. 1987. The effect of moderate salt stress on leaf anatomy in Hibiscus cannabinus (Kenaf) and its relation to leaf area. Amer J Bot 74: 538-542.

Dolatabadian ASA, Modarres M, Sanavy, Ghanati F. 2011. Effect of salinity on growth, xylem structure and anatomical characteristics of soybean. Not Sci Biol 3 (1): 41-45.

Delfine S, Alvino A, Zacchini M, Loreto F. 1998. Consequences of salt stress on conductance to $\mathrm{CO}_{2}$ diffusion, rubisco characteristic dan anatomy of spinach leaves. Australian J Plant Physiol 25: 395-402.

Fagbola O, Osonubi O, Mulongoy K, Odunfa SA. 2001. Effect of drough stress and arbuscular mycorrhiza on the growth of Gliricidia sepium (Jacq). Walp, and Leucaena leucocephala (Lam.) de Wit. in simulated eroded soil conditions. Mycorrhiza 11:215-223.

Farhoudi R, Modhej A, Afrous A. 2015. Effect of salt stress on physiological and morphological parameters of rapeseed cultivars. J Sci Res Dev 2 (5): 111-117.

Follet RH, Murphy LS, Donahuc RI. 1981. Fertilizer and Soil Amendments. Prentice Hall Inc., Englewood, NJ.

Fischer RA, Maurer R. 1978. Drought resistance in spring wheat cultivars: I. Grain yield responses. Aust J Agric Res 29: 897-912.

Gardner FP, Pearce RB, Mitchell RL (eds.). 2003. Physiology of Crop Plants, Scientific Publishers, Jodhpur, India.

Hameed M, Ashraf M. 2008. Physiological and biochemical adaptations of Cynodon dactylon (L.) Pers. from the Salt Range (Pakistan) to salinity stress. Flora 203: 68-694.

Jaleel CA, Gopi R, Sankar B, Gomathinayagam M, Panneerselvam R. 2008. Differential responses in water use efficiency in two varieties of Catharanthus roseus under drought stress. Comp Rend Biol 331: 42 47.

Jampeetong A, Brix H. 2009. Effect of $\mathrm{NaCl}$ salinity on growth, morphology, photosynthesis and proline accumulation of Salvia natans. Aquat Bot 91: 181-186.

Kamrani MH, Hosseinniya H, Chegeni AR. 2013. Effect of salinity on the growth characteristics of canola (Brassica napus L.). Tech J Engin App Sci 3 (18): 2327-2333.

Lestari GW, Solichatun, Sugyarto. 2008. Pertumbuhan, kandungan klorofil, dan laju respirasi tanaman garut (Maranta arundinacea L.) setelah pemberian asam giberelat (GA3). Bioteknologi 5 (1): 1-9. [Indonesian].

Li R, Guo PM, Baum S, Grando S, Ceccarelli. 2006. Evaluation of chlorophyll content and fluorescence parameters as indicators of drought tolerance in barley. Agric Sci China 5 (10): 751-757.

Lopez PL, Ballesta M, Maurel C, Carvajal M. 2009. Changes in plasma membrane composition of Broccoli roots as an adaptation to increase water transport under salinity. Phytochemistry 70: 492-500.

Mahboobeh R, Akbar EA. 2013. Effect of salinity on growth, chlorophyll, carbohydrate and protein contents of transgenic Nicotiana plumbaginifolia overexpressing P5CS gene. E3 J Environ Res Manag 4 (1): 163-170.

Munns R, Tester M. 2008. Mechanisms of salinity tolerance. Ann Rev Plant Biol 59: 651-681.
Munns R. 1993. Physiological responses limiting plant growth in saline soils: some dogmas and hypotheses. Plant Cell Environ 16: 15-24.

Ogle D, St. John L. 2010. Plants for saline to sodic soil conditions. Tn Plant Materials. 9A: 1-10

Parida AK, Das AB. 2005. Salt tolerance and salinity effects on plants: a review. Ecotoxicol Environ Saf 60: 324-349.

Qiu DL, Lin P, Guo SZ. 2007. Effects of salinity on leaf characteristics and $\mathrm{CO}_{2} / \mathrm{H}_{2} \mathrm{O}$ exchange of Kandelia candel (L.) Druce seedlings. J For Sci 53 (1): 13-19.

Ramezani E, Sepanlou MG, Badi HAN. 2011. The effect of salinity on the growth, morphology and physiology of Echium amoenum Fisch. \& Mey. African J Biotechnol 10 (44): 8765-8773.

Reginato MA, Reinoso H, Llanes AS, Luna MV. 2013. Stomatal abundance and distribution in Prosopis strombulifera plants growing under different iso-osmotic salt treatments. Amer J Plant Sci 4: 80-90.

Singh PK, Chaturvedi VK. 2014. Impact of cinnamic acid on physiological and anatomical changes in maize plants (Zea mays L.) grown under salinity stress. J Stress Physiol Biochem 10: 44-54.

Shrestha SL, Kang WH. 2016. Stomata length and density as an indicator of ploidy level in sweet pepper (Capsicum annuum L.). Res J Recent Sci 5: 4-10.

Soheilikhah Z, Karimi N, Ghasmpour HR, Zebarjadi AR. 2013. Effects of saline and mannitol-induced stress on some biochemical and physiological parameters of Carthamus tinctorius L. varieties callus cultures. Australian J Crop Sci 7 (12): 1866-1874.

Stepien P, Klobus G. 2006. Water relations and photosynthesis in Cucumis sativus L. leaves under salt stress. Biologia Plantarum 50 (4): 610-616.

Syafi R. 2008. Morphological and Physiological Responses of VARIOUS Jatropha curcas L. Genotypes to Drought Stress [Thesis].. Bogor Agriculture Institute, Bogor. [Indonesian]

Syakir M, Maslahah N, Januwati M. 2008. Pengaruh salinitas terhadap pertumbuhan, produksi dan mutu Sambiloto (Andrographis paniculata Nees). Bul Littro 19 (2): 129-137.

Turan MA, Elkarim AHA, Taban N, Taban S. 2009. Effect of salt stress on growth, stomatal resistance, proline and chlorophyll concentrations on maize plant. African J Agric Res 9: 893 -897.

Weidner MS, Petersen MJ, Jensen NW. 2007. US Patent 7252845Synergistic compositions containing aromatic compounds and terpenoids present in Alpinia galanga. US Patent Issued in August. 7, 2007.

Yadav AC, Mangel JC, Lal S, Sharma SK, Kapoor A. 2001. Effect of salinity and phosphorus on growth and yield of potato CV. Kufri Sutlej. J Indian Potato Assoc 28: 30-31.

Ying Y, Baoan L. 2006. 1'S-1'-Acetoxychavicol acetate isolated from Alpinia galanga inhibits human immunodeficiency virus type 1 replication by blocking Rev transport. J Gen Virol 87: 2047-2053.

Younis A, Riaz A, Ahmed I, Siddique MI, Tariq U, Hameed M, Nadeem M. 2014. Anatomical changes Induced by $\mathrm{NaCl}$ stress in root and stem of Gazania harlequin L. Agric Commun 2 (3): 8-14.

Yuwono NW. 2009. Build soil fertility on marginal land. Jurnal Ilmu Tanah dan Lingkungan. 9 (2): 137-141. [Indonesian].

Vankar PS, Tivari V, Singh IW, Swapana N. 2006. Antioxidant properties of some exclusive species of Zingiberaceae family of Manipur. Electr J Environ Agric Food Chem 5 (2): 1318-1322.

Zhao GQ, Ma BL, Ren CZ. 2007. Growth, gas exchange, chlorophyll fluorescence and ion content of naked oat in response to salinity. Crop Sci 47 (1): 123-131. 